\title{
Comparing and Connecting: Comacchio and the Early Medieval Trading Towns
}

\section{Citation}

Michael McCormick. 2013. Comparing and connecting: Comacchio and the early medieval trading towns. In From one sea to another: Trading places in the European and Mediterranean early Middle Ages, ed. Sauro Gelichi and Richard Hodges, 477-502. Proceedings of the International Conference, Comacchio 27th-29th March 2009. Turnhout Brepols Publishers.

\section{Published Version}

10.1484/M.SCISAM-EB.1.101105

\section{Permanent link}

http://nrs.harvard.edu/urn-3:HUL.InstRepos:11373153

\section{Terms of Use}

This article was downloaded from Harvard University's DASH repository, and is made available under the terms and conditions applicable to Open Access Policy Articles, as set forth at http:// nrs.harvard.edu/urn-3:HUL.InstRepos:dash.current.terms-of-use\#OAP

\section{Share Your Story}

The Harvard community has made this article openly available.

Please share how this access benefits you. Submit a story.

\section{Accessibility}


Comparing and connecting: Comacchio and the early medieval trading towns

Michael McCormick

Department of History

Harvard University

Early medieval archaeologists and historians investigating the same phenomena in different regions need to compare their results and methods. Unknown trading worlds are emerging from Africa to Rus, via the North Sea and the Adriatic. At Comacchio specialists discovered each other's discoveries and created intellectual contacts and communications across geographic and disciplinary boundaries that still are too rarely broken. Reflecting on connections and comparisons was inevitable among so many scholars working on so many early medieval trading settlements. The remarkable information starting to come from the Adriatic excavations gains from new understanding developing out of the more established investigations in the north, even as the Adriatic poses its own questions for other regions. Our papers could not help but evoke common features shared by the emporia that sprang up on opposite shores of Europe in the late seventh, eighth and ninth centuries. A non-exhaustive check list of features which characterize many emporia today helps clarify what was distinctive about them as a group and invites future investigation into how, at different times, each may have differed. Some shared features seem systemic; others are material ${ }^{1}$.

At the top of the systemic list stands location. The emporia appeared overwhelmingly in transition zones of differing kinds, particularly ecological, transport, and political or cultural ones ${ }^{2}$. Multiple marginalities are typical. Ecological transition marks the lagoons of Comacchio and Venice on the edge of salt and fresh water. Shifts in transport infrastructure are equally characteristic: at Comacchio, Dorestad, and Venice goods must have moved from river boats or, at least in Venice's case, also overland transport, to sea-going ships and vice versa. Comacchio and Venice lay close to the cultural and political frontier between the Italo-Byzantine and Lombard-Frankish zones, as indeed Haithabu/Hedeby did with respect to the Danes and the Franks.

\footnotetext{
${ }^{1}$ The fruitfulness of this approach is well established, starting from the pioneering typology and gazeteer of emporia developed by R. Hodges, Dark Age economics. The origins of towns and trade, A.D. 600-1000. 2nd ed., London, 1989, p. 50-86, the promised new edition of which is eagerly awaited.

${ }^{2}$ M. McCormick, "Where do trading towns come from?" in Post-Roman Towns, Trade and Settlement in Europe and Byzantium, ed. J. Henning, 1, Berlin, 2007 (Millennium Studies 5), p. 41-68.
} 
Political boundaries raise the important question of royal power in creating emporia. I have argued elsewhere that, for some emporia, evidence for royal initiative is weak at best. This is very different from political authorities who sought to capitalize on or control and tax trading settlements that had already come into existence. New or old evidence undermines many classic cases of purported royal foundation: the Frankish royal annalist's assertion that the king of the Danes created Haithabu by transporting merchants there by force in 808 ignores the archaeological fact that activity had started on the site a full sixty years earlier. The princely authority once credited with the even deposit of the sand layer on which Ribe was built turns out, literally, to have been wind ${ }^{3}$. At the Comacchio conference, Joachim Henning showed that Baltic peasants were capable of laying out even plots of the sort frequently attributed to royal power ${ }^{4}$. What about Comacchio?

The new settlement was born just as nearby Ravenna's main port at Classe was fading away ${ }^{5}$. Comacchio sprang up some five kilometers east of the main Roman road leading from Ravenna to Spina ${ }^{6}$. By that road, the exarchate's capital stood over half a day's distance to the south, about thirty kilometers, if anyone traveled overland rather than by boat. Today the open salt ponds of Le Valli lie between Comacchio and Ravenna. If they existed in our period, at some ten $\mathrm{km}$ across they may well have complicated getting to Comacchio by land, as indeed the curve in the Roman road suggests. In other words, Comacchio looks paradoxically close to but separated from Ravenna.

But why should one have done business in tiny Comacchio rather than Ravenna? It cannot have been in order to get closer to a bigger population and therefore to a bigger

\footnotetext{
3 For both cases, details in McCormick, "Where do trading towns come from?", 44-46; R. Fleming also has mounted a vigorous assault on the idea of princely foundation of the Anglo-Saxon emporia: R.

Fleming, "Elites, boats, and foreigners: rethinking the birth of English towns", in Città e campagna nei secoli altomedievali, 1, Spoleto, 2009 (Settimane de studio del centro italiano di studi sull'alto medioevo 56), p. 393-425.

4 Joachim Henning discussed archaeological evidence from Rügen for this in the paper he delivered at the Comacchio conference.

${ }^{5}$ E. Cirelli, Ravenna: archeologia di una città, Borgo San Lorenzo, 2008 (Contributi di archeologia medievale 2), p. 138; cf. p. 165; A. Augenti, "Ravenna et l'alto Adriatico: sfere di interazione. Una prospettiva archaeologica", in Felix Ravenna: la croce, la spada, la vela: l'alto Adriatico fra V e VI secolo, eds. A. Augenti, C. Bertelli, Milan, 2007, p. 27-32, at p. 32.

${ }^{6}$ As depicted in R. J. A. Talbert, ed., Barrington Atlas of the Greek and Roman World, Princeton, 2000, map 40; cf. M. McCormick, G. Huang, K. Gibson, M. Polk, ed., "The Roman empire," The Digital Atlas of Roman and medieval civilization, at http://isites.harvard.edu/icb/icb.do?keyword=k40248.
} 
market if, as Salvatore Cosentino has suggested, some 10,000 people still lived in contemporary Ravenna ${ }^{7}$. Was the demand that Comacchio served originally located at Ravenna and did it shift only later to the Po basin? Or were Comacchio's imports geared to the Po valley right from the start? Did Ravenna cease having good direct water connections with the Po system or with the Adriatic such that navigational difficulties pushed shipping northward to a new hub? The answers to these questions must come as much from geology as archaeology, from the finer chronology of the alluvial deposits which pushed the modern beach so far from today's Ravenna. They should shed considerable light on the role changing environmental and navigational factors may have played in the birth of the new town.

In any case, I suspect a good part of the answer lies in what Ravenna had that Comacchio lacked, at least at the moment when we now see the first stirrings of Comacchio's commercial activity. And that was government: administration, customs dues, and Byzantine regulation and taxes. Maybe the initial stimulus for Comacchio's origin was its offshore status, a place where small-scale merchants could discretely transact business without worrying about the transaction costs of taxes and customs duties, not to mention possible strictures on trading with the Lombard enemy during times of military conflict. We can see such restrictions most clearly two generations later, during the final war to conquer Ravenna, when the Lombard king sought to throttle his own people's commerce with the "Romans," which surely included the Roman or Byzantine citizens of Comacchio and Venice ${ }^{8}$. Formal Byzantine trade with the warring Lombards was presumably regulated or barred long before that. With its prohibitions on trading with barbaricum, with territories controled by the barbarians, the Justinianic

\footnotetext{
${ }^{7}$ See in this volume, Cosentino, *[please supply title].

${ }^{8}$ Ahistulfi leges de anno I (A.D. 750), 4, ed. F. Beyerle, Die Gesetze der Langobarden, Weimar, 1947, p. 360: "Et hoc item de illis hominibus, qui negotium fecerint sine uoluntate regis cum romano homine...". It is probably no coincidence that the opening paragraph of the 715 Lombard pactum with the Comacchian boatmen refers to the present restoration of times of peace in terms that could evoke recent political as well as judicial conflict: "Judicia homines uestri pararunt; nunc quidem deo auxiliante remota sunt, ut pacis temporibus pars parti perfruamur": Pactum, ed. L. M. Hartmann, Zur Wirtschaftsgeschichte Italiens im frühen Mittelalter. Analekten, Gotha, 1904, p. 123-124.
} 
Code remained the law of the land in Byzantine Italy, including Ravenna and, if any officials set foot there, Comacchio 9 .

If "offshore" and unregulated status was the attraction, Comacchio fit a broader pattern. It goes back at least to the fifth century, when emperor Valentinian III tried to outlaw what he called "stealthy business" (furtiva negotiatio): merchants were avoiding official business places and doing deals "in obscure and hidden places" where there were no tax collectors ${ }^{10}$. Down to the Lombard conquest, the apparatus of the RomanoByzantine state with its well-established administrative routines, institutions and taxes ruled Ravenna and its markets. That may well be why Comacchio is not at Ravenna. Of course nature, geology and the silting of the Po at Ravenna might have had a word to say as well.

A second systemic feature follows from the emporia's marginal location and leads to the first of the material features that characterize many of them. As Stéphane Lebecque observed, the emporia tended to be relatively isolated from densely populated areas ${ }^{11}$. This seems paradoxical in the light of their commercial vocation. That necessitated markets which required significant populations. But it may well be connected with the fact that at the outset the emporia mostly lacked formal defensive structures. Building walls added to the costs of having an emporium; isolated sites in ecologically marginal zones needed less defending. Comacchio, Rialto, Torcello, Dorestad, Birka, Walcheren or Ladoga for instance, were all in some way completely or partially separated from their surrounding territories. This must have discouraged at least casual attempts at robbery or raiding. It also made it easier to police comings and goings to the site, enhancing the security of those active there, even as it may have lent the site a kind of politically neutral character such that, in some cases, they seem almost to lie in a kind of no man's land.

The absence of ramparts until late in their existence may provide another clue: for long the emporia enjoyed and likely required a broader sense of security for their sites to function well economically. The Vikings found the Frankish emporia easy pickings. The

\footnotetext{
${ }^{9}$ For the laws against exporting to the barbarians wine, oil, garum and weapons or gold: Codex Iustinianus, 4, 41, 1-2, ed. P. Krueger, Berlin, 1915, p. 178-179; cf. ibidem, 4, 63, 2, 188. Whether and how regularly they were enforced is an important and open question.

${ }^{10}$ Valentinian III, Novella 24 (25 April 447), Codex Theodosianus, ed. P. Krueger and T. Mommsen, 2 , Berlin, 1905, p. 117-118: “...ne ulterius furtiva negotiatio et claris urbibus rarum faciat mercatorem et obscuris et reconditis locis in damnum publicae functionis lateat turba mercantum...".

${ }^{11}$ Stéphane Lebecq, *[please supply title] in this conference.
} 
Arabs had a harder time with Venice, which had faced multiple attacks earlier in the ninth century; Comacchio on the other hand did fall to them in 875 when Venice seems not to have been directly attacked ${ }^{12}$. It is perhaps no coincidence that when walls did go up, that tended to occur toward the end of an emporium's life-span, when the wealth long generated by a place seemed to justify the investment. Yet the expenditure apparently would not suffice to save some market settlements. The question of the relative defendability of a dying emporium's site versus that of its successor town may shed some light on the shifts from, say, Haithabu to Schleswig or from Dorestad to Tiel.

The ramparts that still mark for us the late stages of northern emporia's existences demarcate their size at that time. We need always to take into account the differing sizes of the emporia and how they may have grown or shrunk over time. As anyone who has actually visited both sites will recognize, Haithabu is physically bigger than Birka. What does that mean in economic and historical terms? Does it reflect a more thinly populated hinterland for Birka than in Haithabu's? How will Haithabu's hectares compare to those of Quentovic, Dorestad or Hamwic in the same decades? Obviously the task does not get any easier with emporia that began as polyfocal settlements such as the early Venetian nuclei or, apparently, Comacchio. But measuring the relative spatial extent and differing topographical structures of different emporia and how they changed are indispensable to gauging their growth, contraction and comparative significance. ${ }^{13}$ This will supply some signals about how individual trading settlements may have functioned within the broader system.

Trash in substantial qualities also marks the denser human population and economic activities that characterized emporia. Their waste management practices require careful comparative study; they illuminate both the taphonomic processes that have shaped the archaeological record and the organization and governance --or lack thereof-- of each town ${ }^{14}$. Ingenious investigation has shown how, for instance, at Birka,

\footnotetext{
${ }^{12}$ M. McCormick, Origins of the European economy. Communications and commerce, A.D. 300-900, Cambridge, 2001, p. 949, no. 628: the Venetians successfully defended Grado from a two-day siege by Arab raiders, who then sailed to and sacked Comacchio.

${ }^{13}$ Hodges, Dark Age economics, p. 63-64, with Figure 13.

${ }^{14}$ From a different sort of site, see the exemplary discussion of C. Loveluck, D. Atkinson, eds., The early medieval settlement remains from Flixborough, Lincolnshire: the occupation sequence, c. AD 600-1000, Oxford, 2007 (Excavations at Flixborough 1), p. 60-67, p. 70-80, p. 82, p. 87-96; cf. M. Canti, "Geoarchaeological studies at Flixborough-North Conesby: understanding the burial environment,
} 
winter garbage was simply left on the ice of the frozen lake in front of the town until the spring melt caused it to drop to the lake bottom a few feet off shore ${ }^{15}$. Beyond quantity, emporium garbage should look qualitatively different from that of surrounding rural sites. We would expect refuse testifying to exceptional levels and varieties of craft-production whether it takes the form of the apparent glass wasters in Comacchio or the paws from fur pelts at Birka ${ }^{16}$. The concentration of wealth that occurs in a place given over to making money inclines one to expect among the household garbage signs that at least some residents enjoyed a distinctive diet that may have signaled luxury status ${ }^{17}$. Perhaps the trash might also shed some light on the differing social structures of the emporia. A Christian woman (matrona) who lived at Birka could have herself been a merchant or head of a merchant household, for Frideburg was very wealthy ("in saeculi quoque rebus dives") and had manifestly been to Dorestad, for she tells her daughter that, unlike Birka, it was filled with churches and clergy. Frideburg decided that her daughter should travel 1300 some $\mathrm{km}$ to Dorestad to distribute her bequest of alms to the many poor people who lived there. "Because," she said, "there are fewer poor people here"18. That could mean simply that Birka was smaller than Dorestad, as indeed it probably was. It could also, however, suggest that the distribution of wealth looked different in the Scandinavian trading town compared to the Frankish one, a proposition which differing patterns of food consumption might well clarify.

\footnotetext{
taphonomy and preservation conditions", in ibidem, p. 17-23, and the overview in C. Loveluck, Rural settlement, lifestyles and social change in the later first millennium AD: Anglo-Saxon Flixborough in its wider context, Oxford, 2007 (Excavations at Flixborough 4), p. 12-18.

${ }^{15}$ J. Risberg, S. Karlsson, A.-M. Hansson, et al., "Environmental changes and human impact as recorded in a sediment sequence offshore from a Viking Age town, Birka, in southern Sweden”, The Holocene, 12 (2002), p. 445-458.

${ }^{16}$ For later seventh-century wasters from glass blowing: M. Ferri, "Glass: production and material traces", in L'isola del vescovo. Gli scavi archeologici intorno alla Cattedrale di Comacchio. The archaeological excavations nearby the Comacchio cathedral, ed. S. Gelichi, Florence, 2009, p. 33-35; cf. also the earlier find of a probable waster: S. Gelichi, C. Negrelli, G. Bucci, et al., "I materiali di Comacchio", in Uomini, territorio e culto dall'Antichità all'Alto Medioevo. Genti nel Delta. Da Spina a Comacchio. Catalogo della mostra. 16 dicembre-14 ottobre 2006, ed. S. Gelichi, Ferrara, 2007, p. 601-659, here p. 639. Paws and fur processing at Birka and other settlements: B. Wigh, Animal husbandry in the Viking age town of Birka and its hinterland, Stockholm, 2001 (Birka Studies 7), p. 120-123.

${ }^{17}$ See on the problem in general the insightful essay of A. Ervynck, W. Van Neer, H. Hüster-Plogmann, et al., "Beyond affluence: the zooarchaeology of luxury", World Archaeology, 34 (2003), p. 428-441.

18 Vita Anskarii auctore Rimberto, 20, ed. G. Waitz, Hanover, 1884 (Monumenta Germaniae historica, Scriptores rerum Germanicarum in usum scholarum), p. 44-46. I have calculated the distance via Google Earth, and assumed a portage across the neck of the Jutland peninsula at Haithabu.
} 
Money or at least concentrated moveable wealth such as hacksilver, gold or silver ingots or rings should be present in quantities that distinguish an early trading settlement from its surroundings. Hoards may not be surprising, but single stray coins suggest more reliably how wealth circulated in the emporium. Both give a revealing image of a place's nearer and further trading partners. This is certainly so at Dorestad. Even if Frankish authorities successfully limited the circulation of foreign issues north of the Alps, coins converged there from all over the Carolingian empire, including mints as far afield as Italy and Spain ${ }^{19}$. At Kaupang, Carolingian and Anglo-Saxon coins occur alongside hacksilver and Arab dirhams ${ }^{20}$. So far, only one Carolingian penny has shown up at Comacchio, and it was struck at the nearby mint of Venice ${ }^{21}$. Arab dinars and dirhams circulated intensively in early medieval Venice ${ }^{22}$. Demand for easy standards of exchange will have encouraged the minting of money in the emporia. This was certainly true of Quentovic, Dorestad, and possibly Haithabu and Ribe ${ }^{23}$. So too if at first sight rather paradoxically at Venice.

In fact, the demand for coins in the emporia was so strong that established mints sometimes had difficulty meeting it. At least that is what the proliferation of imitation coins suggests. These are coins whose legends and design show they do not come from an official mint, but whose other features have not --thus far-- suggested that their metal content was so low that they aimed at outright fraud. A number of coins that might fall into this category bear the Dorestad mint name, and imitation coins seem in general common in Carolingian Frisia ${ }^{24}$. An even more interesting insight comes from a new

\footnotetext{
${ }^{19}$ H. Enno van Gelder, "Coins from Dorestad, Hoogstraat 1", in Excavations at Dorestad. Hoogstraat, eds. W. A. Van Es, W. J. H. Verwers, Amersfoort, 1980 (Nederlandse oudheden 9), p. 212-224, at p. 221-224.

${ }^{20}$ M. Blackburn, "The coin-finds", in Means of exchange: dealing with silver in the Viking age, ed. D. Skre, Aarhus, 2007 (Kaupang excavation project 2), p. 29-74, and B. Hårdh, "Hacksilver and ingots", in ibidem, p. 95-118.

${ }^{21}$ S. Gelichi, ed., L'isola del vescovo, p. 19.

${ }^{22}$ McCormick, Origins, p. 330-335 and p. 361-369.

${ }^{23}$ Coin production at Haithabu remains controversial. See, e.g., H. Steuer, W. B. Stern, G. Goldenberg, "Der Wechsel von der Münzgeld- zur Gewichtsgeldwirtschaft in Haithabu um 900 und die Herkunft des Münzsilbers im 9. und 10. Jahrhundert”, in Haithabu und die frühe Stadtentwicklung im nördlichen Europa, eds. K. Brandt, M. Müller-Wille, C. Radtke, Münster, 2002 (Schriften des Archäologischen Landesmuseums 8), p. 133-167, and B. Malmer, "Münzprägung und frühe Stadtbildung in Nordeuropa", in Haithabu und die frühe Stadtentwicklung im nördlichen Europa, eds. K. Brandt, M. Müller-Wille, C. Radtke, Münster, 2002 (Schriften des Archäologischen Landesmuseums 8), p. 117-132.

${ }^{24}$ See e.g., P. Grierson, M. Blackburn, Medieval European coinage 1, Cambridge, 1986, p. 217 and, on the imitation gold coins, often of poor quality and therefore closer to or indeed outright counterfeits, p. 329-30; 532, nos. 519-520; cf. on Dorestad coins which he was inclined to attribute to an unofficial mint: Enno van
} 
scientific analysis of Carolingian coins. It has always seemed strange that Venice struck Frankish silver pennies. As the dating formulas of Venetian documents tend to confirm, ninth-century Venice was technically a part of the Byzantine empire ${ }^{25}$. Indubitably authentic, the coins are nevertheless systematically lighter than the coins struck in mints that the Carolingian kings really controled ${ }^{26}$. Recent laser ablation inductively coupled plasma mass spectroscopy (LA-ICP-MS) of the specimens preserved in the Cabinet des Médailles of the Bibliothèque nationale de France has revealed yet another surprise: the eighteen Venetian coins contained significantly less silver than contemporary standard Frankish issues $^{27}$. Their wide circulation in the Carolingian empire and, so far, their total absence from Venice itself -although, as mentioned, not from Comacchio, where one has turned one up in the Piazza XX Settembre excavation-- seem to mean that Venice paid for whatever it bought from the mainland with Frankish coins that it minted itself ${ }^{28}$. The further implication is that Venice profited twice over, making the standard benefit that came from minting coins, and enjoying a discount by paying for its purchases with a coin that was not only lighter, but that contained ten to twenty percent less silver than normal Frankish coins. It seems undeniable that we have here a conscious policy aimed at maximizing profit. In terms of the typology of economic behavior developed by the economist Peter Temin, this can only signify an "instrumental" mindset, that is, one that

Gelder, "Coins from Dorestad, Hoogstraat 1", at p. 218, concerning his p. 219, nos. 9-14; S. Coupland, "Dorestad in the ninth century: the numismatic evidence", Jaarboek voor munt- en penningkunde, 75 (1988), p. 5-26, at p. 18-19, challenges some of these interpretations, but there are other cases that he is inclined to admit: S. Coupland, "The coinage of Lothar I (840-855)", The Numismatic Chronicle, 161 (2001), p. 158-190, at p. 191.

${ }^{25}$ See, e.g., the will of doge Justinian of 828-829, dated (with some obvious textual corruptions) "Imperantibus dominis nostris piissimis perpetuis augustis Michaelis et Theophilo a Deo coronatis pacificis magnis imperatoribus, Michaelio quidem maiore imperatore anno nono, Neophilo [sic] vero a Deo coronato eiusque dilecto filio octavodecimo, indicione septima": Ss. Ilario e Benedetto e S. Gregorio, ed. L. Lanfranchi, B. Strina, Venice, 1965 (Fonti per la storia di Venezia, Sez. 2, Archivi ecclesiastici, Diocesi Castellana) no. 2, p. 19. I wonder whether it is significant that during the period when Venice started minting Frankish-style coinage, the doges' grant of 819 avoids mentioning any rulers in its dating formula: ibidem, no. 1, p. 8. On dating and political identity in the region, M. McCormick, "The imperial edge: ItaloByzantine identity, movement and integration, A.D. 650-950", in Studies on the internal diaspora of the Byzantine empire, eds. H. Ahrweiler, A. E. Laiou, Washington, D. C., 1998, p. 17-52, here p. 46-47.

${ }^{26}$ Judging from the Veuillin hoard: Grierson, Blackburn, Medieval European coinage, p. 216.

${ }^{27}$ See G. Sarah, M. Bompaire, M. McCormick, et al., "Analyses élémentaires de monnaies de Charlemagne et Louis le Pieux du Cabinet des Médailles: l'Italie carolingienne et Venise", Revue numismatique, 164 (2008), p. 355-406, Table 2. Eighteen of the nineteen coins analyzed produced usable results. Of these, one had $92 \%$ silver, two, ca. $90 \%$, ten, $81.9-88.6 \%$, five, $72.6-78 \%$. The mode (six coins) ran between 85.2 and $86.9 \%$. By contrast, the six contemporary coins of Carolingian Italy run between 97.6 and $93.6 \%$ fine, with one outlier from Pavia at $84.1 \%$.

${ }^{28}$ Illustrated in Gelichi, L'isola del vescovo, p. 19. 
is geared to markets that operate more or less as we know them ${ }^{29}$. So materials science illuminates the mental disposition of the authority who issued coins in Venice.

Intensive money use brought with it another significant feature of coin circulation in the nascent trading towns: outright counterfeiting was such a part of the monetary spectrum as to rival the discrete cheating of Venetian minters. Thus nine Islamic dirhems recovered in association with a shipwreck in the port of Haithabu: on first examination, they seemed to represent a remarkable set of dirhams struck at the same time in Baghdad and which had traveled together almost to the bank of the Schlei in Jutland. But they have turned out to be counterfeits ${ }^{30}$. Dorestad too was no stranger to counterfeit coins ${ }^{31}$.

The emporia's intensive use of money thus spawned fraud. Small wonder that touchstones appear at Dorestad. They should show up on other emporium sites as well: merchants were well-advised to test the fineness of the money that changed hands ${ }^{32}$. Maybe this is another sign also that the hand of the king lay more lightly on the emporia zones, and that the currency that circulated there was less subject to royal controls. A related feature is the frequency and often sophistication of the scales and weights that occur on such sites ${ }^{33}$. The weight systems themselves can be tricky to reconstitute given the oxydation that often affected the objects, but they are certainly worth investigating. Did Comacchio use a Byzantine, a Roman, a Frankish, or some other weight system or combination of systems? What does the answer to that question tell us about the economic horizons of the place, and how they may have changed over time?

Transport was essential to the trading networks that coalesced in the emporia. So the zooarchaeology of emporia should feature donkeys, mules, horses, and oxen whose relative proportions and spectrum may have changed over time. For instance, the donkeys which were scarcer than hen's teeth in Roman northern Gaul became more frequent

\footnotetext{
${ }^{29}$ P. Temin, "Modes of behavior", Journal of Economic Behavior and Organization, 1 (1980), p. 175-195.

${ }^{30}$ McCormick, Origins, p. 822-823; cf. the new evidence in Steuer, Stern, Goldenberg, "Der Wechsel von der Münzgeld- zur Gewichtsgeldwirtschaft", p. 155-156.

${ }^{31}$ Enno van Gelder, "Coins from Dorestad, Hoogstraat 1", p. 218 on p. 219, nos. 15-17.

${ }^{32}$ E.g., W. A. van Es, W. J. H. Verwers, J. van Doesburg, Excavations at Dorestad 3: Hoogstraat 0, II-IV, Amersfoort, 2009 (Nederlandse Oudheden 16), p. 337; cf. the photograph of the nine Dorestad touchstones in A. Willemsen, Dorestad: een wereldstad in de Middeleeuwen, Zutphen, 2009, p., 122, Afb. 144.

${ }^{33}$ See, e.g., the discussion in Steuer, Stern, Goldenberg, "Der Wechsel von der Münzgeld- zur Gewichtsgeldwirtschaft", with further references.
} 
under the Merovingians and especially the Carolingians ${ }^{34}$. What this new presence of smaller pack animals means in economic terms is an open question. However, one hint comes from a contemporary literary text. It shows a donkey as the main capital resource of a small-time merchant whose travels took him to the vicinity of Quentovic ${ }^{35}$. The donkey's aptness for small-scale transport might therefore signal the involvement at the emporia of retail merchants, peddlars of sorts. Certainly a donkey bone has turned up in the garbage dumped from Haithabu's docks, which comprises mostly kitchen refuse ${ }^{36}$. So far two donkeys may be documented at Dorestad ${ }^{37}$. In the absence of wheelbarrows, human backs did the hard labor of lifting, carrying, rolling and stowing. The spinal columns and limbs of some inhabitants should show patterns of bone formation reflecting long years of such hard labor ${ }^{38}$. Carts, wagons, pack gear, harness fittings and of course boats and ships - or at least pieces of them, recycled into various uses around the emporium--, boathooks and gear of all descriptions should equally distinguish the

\footnotetext{
${ }^{34}$ R.-M. Arbogast, B. Clavel, S. Lepetz, et al., Archéologie du cheval: des origines à la période moderne en France, Paris, 2002, p. 7-8, which reports that donkeys, which are virtually absent from the northern half of modern France until the Merovingian period, begin to appear on about $12 \%$ of rural sites there in the seventh and eighth centuries, and then become common under the Carolingians.

${ }^{35}$ Miracula S. Germani Parisiensis, 13-15, $3^{\text {rd }}$ ed., Paris, 1866 (Acta Sanctorum, Maii 6), p. 782, where "in pago quoque Tarnense" $(13$, p. $782 \mathrm{~A}$; cf. p. $783, \mathrm{n} . d)$ refers to the region of Therouanne which is also that of Quentovic, and the place where the merchant found his future slave abandoned by the side of the road, as indeed Adso of Montier-en-Der confirms: Vita Walberti, 7, ed. M. Goullet, Turnhout, 2003 (Corpus christianorum, Continuatio mediaevalis 1998), p. 79-93, here p. 84.177-178, with Goullet's commentary on p. 98, speaking about a place located at one of two similarly named villages in the region, distant, respectively some 20 and $40 \mathrm{~km}$ from the site of Quentovic; cf. ibidem, 14, p. 88.320-324. See also A. Longnon, Études sur les pagi de la Gaule, 1, Paris, 1869-1872, p. 47-48.

${ }^{36}$ H. Hüster Plogmann, "Untersuchungen an Skelettresten von Säugetieren und Vögeln aus dem Hafen von Haithabu", in Untersuchungen an Skelettresten von Tieren aus dem Hafen von Haithabu, eds. D. Heinrich, H. Hüster Plogmann, U. Schmölcke, et al., Neumünster, 2006 (Berichte über die Ausgrabungen in Haithabu 35), p. 25-156, at p. 71; cf. H. Reichstein, "Erste Nachweise zum Vorkommen vom Hauseseln im mitterlalterlichen Schleswig-Holstein", in Tierknochenfunde der Ausgrabung Schild, 1971-1975, ed. D. Heinrich, Neumünster, 1995 (Ausgrabungen in Schleswig. Berichte und Studien 11), p. 179-187; on the find circumstances, D. Heinrich, "Die Tierknochen aus dem Hafen von Haithabu. Einführende Bemerkungen", in Untersuchungen an Skelettresten von Tieren, p. 9-24. The small numbers of horses and one donkey in this assemblage does not reflect their real importance in the economy of Haithabu, since the deposit stems overwhelmingly from kitchen refuse: Hüster Plogmann, "Untersuchungen an Skelettresten", p. 70 .

${ }^{37}$ One was identified by the distinguished zoologist Hermann Schlegel (1804-1884), Director of the (National) Natural History Museum of Leyden, from the original excavation in 1842, a specimen whose present whereabouts seems uncertain; the other, a small worked metatarsus, is only tentatively assigned to Equus asinus: W. Prummel, Excavations at Dorestad, 2. Early medieval Dorestad: an archaeozoological study, Amersfoort, 1983 (Nederlandse oudheden 11), p. 33 and p. 217; cf. p. 29-30.

${ }^{38}$ C.A. Roberts, Human remains in archaeology, York, 2009, p. 173-178.
} 
emporia $^{39}$. Given the primordial role of water transport for the networks of the emporia, port structures -docks, mooring stakes, embankments - are a recurring structural feature ${ }^{40}$.

By the same token, remains of transport containers should litter the site. There is small hope of course for perishable sacks or leather wrapping, but once in a while favorable conditions might preserve some scraps as well as baskets or boxes ${ }^{41}$. In a Mediterranean context, amphoras, possibly including some of local manufacture, feature prominently at Comacchio and this must also be true of its Venetian rivals ${ }^{42}$. Barrels probably played a greater role in late Roman trade than we are accustomed to think. The Adriatic rim seems to have been among the early epicenters of the Roman spread of the new container, as we know from texts, sculpture and even the occasional ancient or medieval barrel ${ }^{43}$. Classe Warehouse no. 17, which was destroyed by fire in the late fifth century, featured large numbers of amphoras, but also at least one barrel ${ }^{44}$. So too the unpublished 1996 excavation at Comacchio turned up one or more barrels ${ }^{45}$. Carolingian barrels, presumably once filled with wine, were recycled as wells at Haithabu ${ }^{46}$. In other words, as important as they are, the amphoras excavated in recent years at Comacchio may only represent part of the port's spectrum of transport containers.

Competition between barrels and amphoras in late antiquity and again in the later Middle Ages probably had economic implications. That lends special interest to the

\footnotetext{
${ }^{39}$ For the wheels discovered at Haithabu, see F. Westphal, Die Holzfunde von Haithabu, Neumünster, 2006 (Die Ausgrabungen in Haithabu 11), p. 74. For ships at Haithabu and Dorestad, see, e.g., M. McCormick, K. Gibson and A. M. More, "Concise geodatabase of shipwrecks AD 1-1500," Digital Atlas of Roman and Medieval Civilization (in preparation): "Haithabu 1" and "Haithabu 3," and "Dorestad"; boathooks at Haithabu: P. Westphalen, Die Eisenfunde von Haithabu, Neumünster, 2002 (Ausgrabungen in Haithabu 10), p. 131-132; at Dorestad: van Es, Verwers, van Doesburg, Excavations at Dorestad 3, p. 227.

${ }^{40}$ See for the first indications about dock structures at Comacchio, D. Calaon, "Lo scavo di Villaggio San Francesco 1996 (COM 96). Le strutture portuali di Comacchio?" in Uomini, territorio e culto, p. 505-530; Dorestad: van Es, Verwers, van Doesburg, Excavations at Dorestad 3, p. 50-75.

${ }^{41}$ For written evidence of organic containers, see McCormick, Origins, p. 409-410; a basket at Dorestad: van Es, Verwers, van Doesburg, Excavations at Dorestad 3, p. 243.

${ }^{42}$ C. Negrelli, "Produzione, circolazione e consumo tra VI e IX secolo: dal territorio del Padotevere a Comacchio", in Uomini, territorio e culto, p. 437-471, and Gelichi, Negrelli, Bucci, et al., "I materiali di Comacchio".

${ }^{43} \mathrm{M}$. McCormick, "Movements and markets in the first millennium: information, containers and shipwrecks", in Dumbarton Oaks Symposium on Trade and Markets in Byzantium, ed. C. Morrisson, Washington, D. C., in press, with further references.

${ }^{44}$ Personal communication of Andrea Augenti.

${ }^{45}$ Personal communication of Sauro Gelichi.

${ }^{46}$ See in general Westphal, Die Holzfunde von Haithabu, p. 18 and p. 37-44.
} 
question whether barrels competed with amphoras in the Adriatic emporia. Although barrels were presumably more expensive to make, their capacity efficiency -the relation of the weight of the container to the volume of the contained-seems to have been greater than even the most efficient ancient amphoras. That superiority probably was most evident when it was economically important to transport larger volumes of suitable goods. If late antique wine amphoras ran something like 10 to 60 or so liters in capacity, surviving ancient barrels break down into classes of ca. 3 to 53 liters, 75-100 liters, 460620 liters, 860-1200 liters, and 750-1440 liters. The largest barrels are very well represented, in my opinion for reasons that are more than taphonomic ${ }^{47}$. In the early medieval Mediterranean where amphoras still played a leading role as food transport containers, signs of real competition from barrels could serve as a kind of economic indicator that some merchants were dealing in larger volumes. No less important: when they begin to emerge and be studied, the barrels themselves will yield the secret of the date and place of their origins, as the dendrochronological data from the forests that supplied their wood grow denser and allow more conclusive provenancing. This should help identify from where their wares were coming to the emporia ${ }^{48}$.

All those barrels, amphoras and packs of goods needed to be stored somewhere before and after they changed hands and moved on to the further reaches of trading networks. Storage facilities, warehouses, and storerooms must have been unavoidable features of emporia once they moved beyond a purely seasonal stage of existence. From the storage spaces we may be able to deduce important clues about how goods were kept and trade was organized: can one tell whether storage has been conceived for one or multiple merchants $?^{49}$ Do storage facilities consist of a few large buildings or many small ones? Are they indistinguishable from dwellings, indeed are they part of dwellings? This would indicate that the merchant never let his wares out of his sight; it probably also

\footnotetext{
${ }^{47}$ É. Marlière, L'outre et le tonneau dans l'Occident romain, Montagnac, 2002 (Monographies Instrumentum 22), p. 164-167. For more discussion of barrels in late antique shipping, McCormick, "Movements and markets in the first millennium".

${ }^{48}$ I am grateful to Dr. Willy Tegel for a stimulating conversation about his ongoing dendrochronological research into recently discovered Roman barrels.

${ }^{49}$ For written and archaeological evidence of storage arrangements in the late Roman and medieval Islamic Mediterranean world, see O. R. Constable, Housing the stranger in the Mediterranean world: lodging, trade, and travel in late antiquity and the Middle Ages, Cambridge, 2003, p. 33-35, p. $71-79$ passim, p. 9596, and p. 240-247 passim.
} 
would signify that his or her dealings remained on a fairly small scale. How do the sizes of potential or certain storage space compare among structures, and across different emporia? Did they change over an emporium's lifespan? Are there revealing patterns in where they were located within the topographic fabric of emporia? Obviously the greatest insights would come if archaeologists were lucky enough to identify a warehouse that experienced catastrophic destruction and abandonment. There one might be able to deduce how a merchant understood his trade and his wares from the way that he organized their storage. Did he specialize in types of ware? Or rather in terms of geography and specific networks? One suddenly destroyed warehouse has recently come to light in a Byzantine fort on the Danube; another from late fifth-century Classe is just now in the process of publication. Both promise remarkable new information on shipping and exchange in late antiquity, and we could hope for similar information from similar cases in the emporia ${ }^{50}$. So the full publication of the plot at Birka whose residents seem to have specialized in trade with the East over some three generations can be expected to shed new light on the spatial organization and activities of the most characteristic type of inhabitants of the emporia ${ }^{51}$.

Shabby temples to greed and acquisitiveness, the early trading towns were filled with valuable goods as well as money, real or counterfeit. And so it is no surprise that their residents made ample use of keys and locks to insure that their valuables were not "acquired" by other residents ${ }^{52}$. The human wares traded at the emporia needed to be secured as well, hence the appearance of iron shackles, which probably once figured

\footnotetext{
${ }^{50}$ V. G. Swan, "Dichin (Bulgaria): interpreting the ceramic evidence in its wider context," in The transition to late antiquity: on the Danube and beyond, ed. A. G. Poulter, Oxford, 2007 (Proceedings of the British Academy 141), p. 251-280, esp. p. 252-255; cf. P. Grinter, "Seeds of destruction: conflagration in the grain stores of Dichin," in ibidem, p. 281-288. For the Classe warehouse excavated in 2004-2005, which I had the pleasure of visiting with its excavator, Andrea Augenti, see the preliminary indications and photos in A. Augenti, "Gli scavi 2004-2005 nel porto di Classe --area I", in Felix Ravenna, p. 34-36; Cirelli, Ravenna: archeologia di una città, p. 133, fig. 113 and p. 134. See also for some first reflections on the potential of such sites, McCormick, "Movements and markets in the first millennium".

${ }^{51}$ See the preliminary summary of B. Ambrosiani, "Birka im 10. Jahrhundert unter besonderer Berücksichtigung der Ostverbindungen", in Europa im 10. Jahrhundert. Archäologie einer Aufbruchszeit, ed. J. Henning, Mainz, 2002, p. 227-235, esp. p. 229.

${ }^{52}$ See, e.g., from Dorestad the bronze and iron keys: van Es, Verwers, van Doesburg, Excavations at Dorestad 3, p., 216 and p. 226-227, or the 163 keys and many locks from Haithabu: Westphalen, Die Eisenfunde von Haithabu, p. 170-191.
} 
alongside more ephemeral ropes and wooden yokes to control slaves ${ }^{53}$. Weapons too we may expect in some quantities ${ }^{54}$. Historical reports make clear that the wealth that traders transported needed defending under way. Whether they went about armed in the emporia we do not know, but we must imagine that weapons were part of their professional gear: the merchants with whom St. Anskar traveled to Birka successfully fought off a first pirate attack before losing their wares and wealth to a second one ${ }^{55}$.

Specialized craft production of course characterizes emporia. What was the range of types of such production and how did it change over time? On what scale did individual workshops produce and how did it develop? How many similar workshops operated at any one time? Were crafts organized spatially in specialized zones? If so was that due to special needs, for example, the access to much water and clay required for ceramic manufacture, or efforts to avoid unpleasant emissions? Could it be explained by other reasons, for instance to facilitate delivering shared raw materials or because the size of the settlement encouraged like industries to congregate so clients or suppliers could more easily find them or indeed, because of some sort of implicit "emporium tradition", some set of expectations that emporium dwellers and visitors carried with them? Did trading towns put out some or much of their craft production to sites in their hinterland? How big was that productive hinterland? With respect to Comacchio, how much of the traders' salt was produced in and around Comacchio, and how much may have been acquired elsewhere along the coast? It will be illuminating to compare the emporia on this score.

The transfer of craft production to emporia may well have played a deeper role than realized, if we follow Dagfinn Skre's imaginative argument: when craftsmen took up residence in the permanent trading settlements of the eighth century, they physically and socially left the entourage of magnates where archaeology seems to locate them until

\footnotetext{
${ }^{53}$ Westphalen, Die Eisenfunde von Haithabu, p. 185-187; J. Henning, "Strong rulers-- weak economy? Rome, the Carolingians and the archaeology of slavery in the first millennium A.D." in The long morning of medieval Europe: new directions in early medieval studies, eds. J. R. Davis, M. McCormick, Aldershot, 2008, p. 33-53; textual evidence for organic restraints: McCormick, Origins, p. 741, note 60.

${ }^{54}$ E.g., van Es, Verwers, van Doesburg, Excavations at Dorestad 3, p. 220-222; Westphalen, Die Eisenfunde von Haithabu, p. 226-245.

${ }^{55}$ Rimbert, Vita Anskarii, 10-11, p. 31-32. The hoard of Frankish and Arab coins (including pennies from the mints of Pavia, Rome and maybe from Ravenna) discovered in the Rhine river at Biebrich, deposited around 800 , possibly reflect a traveling merchant's disaster; it included three swords and two lances: see McCormick, Origins, p. 817-818.
} 
then $^{56}$. From this point forward --insofar as their move to the new site will have been permanent, rather than seasonal-- the artisans could no longer fall back on the chief's largess when they were hungry. On the contrary, the social freedom that scholars impute to the emporia made the craftsmen's daily bread utterly dependent on their production. They thus gained a new incentive to up the pace of their production. According to Skre this could well explain the surge in standardized production he observes in the nodal markets at this time and, in any case, craftsmen established in emporia had to produce more to sell regularly in order to eat regularly. At the same time, he observes, the increased volume of transactions that became part of the craftsman's life must have raised his awareness of the economic -in Temin's typology of economic behavior, in the instrumental-- nature of the transactions in which he daily engaged ${ }^{57}$. In other words, a mentality of trade and profit intensified from the moment a skilled artisan stepped out of his social embeddedness in the leader's household. He was taking an important step toward developing the mental disposition to trade and innovation that Carlo Cipolla saw as so distinctive of Europe's medieval cities ${ }^{58}$.

Craft production requires raw or semi-finished materials. What traces of movements of raw materials or semi-transformed goods can be detected on the ground and from written sources? As our knowledge of the emporia deepens, it will be important to fill in the picture of the feeder networks. For the furs that must have figured so prominently in the northern emporia's wares, some important insights have begun to emerge with the discovery of that refuse from a fur preparation workshop in Birka. The removal of the paws with which the pelts had arrived in Birka mark the craft site and give important information on the different species hunted; it would be highly desirable to extend the scientific analysis of these materials, for instance in testing the remains for stable isotope values that might help specify where the animals had been trapped ${ }^{59}$. This

\footnotetext{
${ }^{56}$ See D. Skre, "*[Add Title of his paper.]"

${ }^{57}$ Temin, "Modes of behavior".

${ }^{58}$ C. M. Cipolla, Before the Industrial Revolution: European society and economy, 1000-1700, 2nd ed, London, 1981, p. 146-149.

${ }^{59}$ Wigh, Animal husbandry, p. 120-123. Some idea of the potential can be gleaned from the survey of methods and results for human movements detected from dental enamel: P. Budd, A. Millard, C. Chenery, et al., "Investigating population movement by stable isotope analysis: a report from Britain", Antiquity, 78 (2004), p. 127-141; see in general: K. A. Hobson, "Tracing origins and migration of wildlife using stable isotopes: a review", Oecologia, 120 (1999), p. 314-326; for an application to early medieval animal migration, see M. M. Schweissing, G. Grupe, "Tracing migration events in man and cattle by stable
} 
in turn would test and expand what we can glean from Ohthere's description of the northern fur trading that supplied the late ninth-century emporia ${ }^{60}$.

A southern raw material whose origins segregate promisingly between the western and central Alps is soapstone. The thermal qualities and workability of vessels made from it encouraged wide trading soapstone cookware aroaund early medieval Italy. Advanced scientific methods distinguish the production zones. Soapstone extracted from the western Alps displays a distribution pattern geared to western and central Italy that may well reflect Tyrrhenian trading networks. ${ }^{61}$ In our period, stoneware whose chemical signature indicates they were extracted from central Alpine deposits near Chiavenna occur in at least two sites on the central Adriatic coast, at Pescara and Lanciano ${ }^{62}$. Further research will fill in the geography and chronology of the finds, including most importantly the situation at Comacchio and whether working of the fire-resistant stone occurred there, but an obvious first hypothesis is that Chiavenna soapstone traveled down Lake Como to the Adda, and from there to the Po and on to the Adriatic emporia and hence to their further trading areas ${ }^{63}$.

To date, the most detailed information about such feeder networks comes in what we can piece together from the written sources about slave hunting in Europe in the age of the emporia. Texts show that slaves were a part of trading places' business: Verdun, of course, but also Birka and Venice are explicitly documented ${ }^{64}$, even if, so far, no one has identified where exactly slaves were held in the emporia. It will be most important to devise ways of tracking the slave trade archaeologically. Here the burgeoning exploration

strontium isotope analysis of appositionally grown mineralized tissue", International Journal of Osteoarchaeology, 13 (2003), p. 96-103.

60 J. Bately, "Text and translation: the three parts of the known world and the geography of Europe north of the Danube according to Orosius' Historiae and its Old English version”, in Ohthere 's Voyages. A late 9thcentury account of voyages along the coasts of Norway and Denmark and its cultural context, eds. J. Bately, A. Englert, Roskilde, 2007 (Maritime Culture of the North 1), p. 40-50, at p. 46.

${ }^{61}$ For the western distribution pattern, see P. Santi, A. Renzulli, F. Antonelli, et al., "Classification and provenance of soapstones and garnet chlorite schist artifacts from medieval sites of Tuscany (Central Italy): insights into the Tyrrhenian and Adriatic trade", Journal of Archaeological Science, 36 (2009), p. 24932501; for the scattered evidence from the written sources for Tyrrhenian shipping and trading networks in the early Middle Ages, see McCormick, Origins, p. 515-521, p. 625, and p. 633-636.

${ }^{62}$ P. Santi, F. Antonelli, A. Renzulli, "Provenance of medieval pietra ollare artefacts found in archaeological sites of central-eastern Italy: insights into the Alpine soapstone trade", Archaeometry, 47 (2005), p. 253-264.

${ }^{63}$ Santi, Antonelli, Renzulli, "Provenance of medieval pietra ollare artefacts", here p. 263, on the river route.

${ }^{64}$ See the discussion and further references in McCormick, Origins, p. 759-768. 
of the more recent west African slave trade offers suggestive examples ${ }^{65}$. Beyond their geographical specification, the human dimension of the remote starting points of these feeder networks is also an important but hithertho almost unnoticed aspect of the historical and economic impact of the emporia. If the merchants themselves are hard to spot outside of the cemeteries of the emporia, we have only the most general ideas about the identity and historical existence of the slave and fur hunters that supplied them ${ }^{66}$. Archaeological detection of northern trappers and slave hunters and their interaction with the people of the emporia could prove revealing.

Skre's intriguing hypothesis seems to presume year-round craft activity by the artisans of the emporia. In the north, there are hints that some emporia began as seasonal settlements, for instance Kaupang and Ribe ${ }^{67}$. How did that change, and what seasonal rhythms marked the life of emporia? One wonders whether some crafts were active only at certain times of year and whether craftsmen varied their occupations by season. For instance, bone workers might have only gotten major supplies of bones for working in the autumn, the traditional time for butchering the animals that supplied most of their raw materials ${ }^{68}$. One can also imagine that the hunting of fur-bearing animals peaked in the winter, when their pelts were at their thickest and most beautiful. This presumably would have caused an influx of pelts into the northern emporia in late winter, spring or early summer, where they would have undergone the kind of further preparation documented at Birka. Considering the annual rhythms of supply, it would be most interesting to try to discover the seasonal rhythms of commercial travel to, from and among the northern emporia. The next question would be to see whether, when or how they might correlate

\footnotetext{
${ }^{65}$ For what is currently underway for African slave migration, see, e.g., Hannes Schroeder, "Isotopes, population genetics, and the transatlantic slave trade: reconciling individual and population-based approaches," paper given at the $3^{\text {rd }}$ International Symposium of Biomolecular Archaeology, York [U.K.], 14-16 September, 2008; abstract at https://sites.google.com/a/palaeo.eu/isba3/Home/abstracts/populations/isotopes-population-genetics-andthe-transatlantic-slave-trade-reconciling-individual-and-population-based-approaches.

${ }^{66}$ For the written evidence on both, see McCormick, Origins, p. 614-669, p. 688-695, and p. 754-777.

${ }^{67}$ K. B. Milek, C. A. I. French, "Soils and sediments in the settlement and harbour at Kaupang", in Kaupang in Skiringssal, ed. D. Skre, [Oslo], 2007 (Kaupang excavation project 1), p. 321-360, at p. 330. ${ }^{68}$ Wigh, Animal husbandry, p. 139, offers evidence for the season of slaughter only for sheep and goats. See the discussion of slaughter patterns and craftwork in Roman settlements in S. Deschler-Erb, "La contribution de l'archéologie à l'étude de l'artisanat romain", in Artisanat et économie romaine: Italie et provinces occidentales de l'empire: actes $d u 3^{e}$ colloque d'Erpeldange (Luxembourg) sur l'artisanat romain, 14-16 octobre 2004, ed. M. Polfer, Montagnac, 2005, p. 31-38.
} 
with those already established for some of the Mediterranean emporia by virtue of the seasonal patterns of southern ship movements.

As the archaeologists intensify their investigation of the Adriatic emporia, seasonality will therefore bear watching there too, through whatever window the taphonomic circumstances and resources and skill of the investigators will allow. Pollen from cores and waterlogged archaeobotanical macrorests retrieved from wet-sieving may be productive. Evidence drawn from other areas can also contribute. The timing of the arrival and departure of shipments from elsewhere in the Mediterranean will have paced the economic life of the Adriatic emporia. Written sources show that the overwhelming majority of ship movements in the early medieval Mediterranean occurred between April and October. Arrivals and departures -that is ports' most active periods-peaked in August. April and June came in second place ${ }^{69}$. The Adriatic rim's distance from the main basins of the great inland sea may have altered the timing somewhat, but the basic pattern probably held. ${ }^{70}$ A second very important parameter will have been laid down by the seasonality of salt production, Comacchio's first great export. Judging from Venice's sixteenth-century records, salt production stretched from May to October, but clearly spiked in August, followed by July and then September ${ }^{71}$. If, as we may suspect, highprotein and easily preserved eels figured prominently in Comacchio's marketable resources in the ninth as in the nineteenth century, then the season of their harvest should have been a third factor that set the port's economic rhythms. In the nineteenth century, the peak catch of eels coincided with their annual autumn migration when they swam out of the lagoon and into the sea at the end of August and the beginning of September ${ }^{72}$.

So the production of two of its core wares as well as the schedule of arrivals of ships with wares from elsewhere in the Mediterranean were summer affairs. Indeed, all peaked about the same time, in August or September. But the really crucial element for making money out of Comacchio must have been the rhythms and time-scales of shipping on the Po and its tributaries, where the Lombard Pactum and subsequent records

\footnotetext{
${ }^{69}$ McCormick, Origins, p. 450-468.

${ }^{70}$ Ibidem, p. 451, note 30 .

${ }^{71}$ J. C. Hocquet, Le sel et la fortune de Venise, Villeneuve-d'Ascq, 1978, 1, p. 227-237, esp. p. 230, Tableau 4.

${ }^{72}$ G. S. Bullo, Previsioni sulla laguna di Comacchio. Provvedimenti, Padua, 1894, p. 7-8.
} 
seem to locate Comacchio's main customers ${ }^{73}$. The wares that arrived or were produced in Comacchio in the summer and early autumn could be sold for a profit at the small towns scattered up and down the Po and its tributaries. A river transport system that covered, very roughly, some $500 \mathrm{~km}$ and served a good number of small markets is nothing to sneeze $a t^{74}$. The modern seasonal regime of the Po suggests that optimal travel conditions -limited flooding - would have occurred in the summer, perhaps from May to September, that is precisely when other activities were reaching a crescendo at Comacchio or indeed even before the eel harvest ${ }^{75}$.

We can gauge more precisely the temporal constraints imposed by the river conditions and distances if we remember that in August 949 it took Liudprand of Cremona only three days to sail more than $400 \mathrm{~km}$ down the Po to Venice from Pavia. He traveled downstream at about five $\mathrm{km}$ an hour or over $130 \mathrm{~km}$ per 24-hour travel day; upstream travel probably took around twice as long, such that towing a boat loaded with goods from Comacchio to Piacenza when the current was not too strong might have taken five or six days without allowing for stops. In sum, a first rough estimate suggests that a round trip up and down the Po to one of places listed in the 715 Pactum implies a minimum of some eight to ten days. It would have grown lengthier with the number and duration of stops along the way. Although these rough and ready estimates should be refined by more detailed research, they offer a rough bench mark of what was possible.

\footnotetext{
${ }^{73}$ Pactum, ed. Hartmann, Zur Wirtschaftsgeschichte Italiens, p. 123-124. Late in the eighth century, the importance of the Po to Comacchio's trade -and its importance to the markets of the Po valley- emerges also from Charlemagne's confirmation of the Pactum during his stay at Parma on 15 March 781, ed. E. Mühlbacher et al., Die Urkunden Pippins, Karlmanns und Karls des Grossen, Hanover, 1906 (Monumenta Germaniae historica, Diplomata Karolinorum 1), no. 132. Comacchio's river traders were still a factor to be reckoned with in the middle of the ninth century, if we may judge from the confirmation of the revenues mentioned in the Pactum sought by the bishop of Cremona from Lothar I: Die Urkunden Lothars I. und Lothars II., ed. T. Schieffer, Berlin, 1966 (Monumenta Germaniae historica, Diplomata Karolinorum 3), no. 116, as well as the diploma of Louis II and the plea before him of the men of Cremona who were trying to compete with the Comacchiesi and Venetians along the Po: Die Urkunden Ludwigs II., ed. K. Wanner, Munich, 1994 (Monumenta Germaniae historica, Diplomata Karolinorum 4), no. 1, and I Placiti del 'Regnum Italiae,' Rome, 1955, 1, ed. C. Manaresi (Fonti per la storia d'Italia 92), no. 56, with McCormick, Origins, p. 927-928, no. 504, and the discussion, p. 778-781.

${ }^{74}$ I used Google Earth to measure the approximate distances along the modern course of the Po to the places mentioned in the Pactum of 715 . See Table.

${ }^{75}$ See on the complex hydrography of the Po and its flood patterns, Autorità di bacino del fiume Po, "Caratteristiche del bacino del fiume Po e primo esame dell'impatto ambientale delle attività umane sulle risorse idriche", http://www.adbpo.it/download/bacino_Po/, consulted 22 September 2009, 2, p. 24-38. The Lombard pactum with the boatmen of Comacchio was established at Pavia on 10 May 715, suggesting that the boats were already moving up the Po at the beginning of May: ed. Hartmann, Zur Wirtschaftsgeschichte Italiens, p. 123.
} 
For starters one can guess that Comacchio boat traders might have made a maximum of twelve to fifteen trips each summer. The actual number of trips will have been considerably less for any boat that spent a day in each of the seven places mentioned as ports or tolling stations in the Pactum.

We can refine the overall estimate by looking at the distances to individual trading or tolling points along the Po. The following table lays out the distances between the places specified by the Pactum of 715 as landings where the Comacchio boatmen paid tolls. The distances correspond to the present course of the Po as measured on Google Earth. Although they probably understate the early medieval trajectories, these distances furnish a rough idea of what the early traders' circuits entailed. Perfection will have to wait until someone can work out the historical hydrography in greater detail using the geological evidence, historical and archaeological evidence, and early modern shipping records.

Distances to trading or tolling places on the Po mentioned by the Pactum of 715

\begin{tabular}{lccc}
\hline Segments & Approximate km & Upstream hours & Downstream hours \\
\hline $\begin{array}{l}\text { Comacchio to the mouth of } \\
\text { the Mincio river }\end{array}$ & 132 & 53 & 26 \\
Mincio mouth to Mantua & 21 & 8 & 4 \\
Mincio mouth to mouth of & 64 & 26 & 13 \\
Parma creek & & & \\
From Parma mouth to Parma & 40 & 16 & 11 \\
Parma mouth to Cremona & 56 & 22 & 3 \\
Cremona to mouth of the & 17 & 7 & 7 \\
Adda river & & & 14 \\
Adda mouth to Piacenza & 33 & 27 & \\
Piacenza to Pavia* & 68 & & \\
\hline Source: Google Earh & & & \\
\hline
\end{tabular}

Source: Google Earth

*Not in the Pactum of 715.

The table indicates that it might have taken around 157 hours for a Comacchian boatman to travel (mostly upstream) in sequence to all of these places as far as Piacenza, and about 60 hours to travel straight downstream from Piacenza to Comacchio, i.e. approximately nine days of non-stop travel. This return trip works out to be a little slower than the river voyage Liudprand reports in the tenth century, but we know nothing about the river 
conditions and the nature of the vessel in which the Liudprand traveled. If we add a day stopover at Mantua, Parma, Cremona, the Adda mouth, and Piacenza, the total trip will have lasted at least two weeks. When boats continued on to Pavia, the trip will have lasted at least two or three days longer. The table furnishes a good first approximation of the economic cost in time of Comacchio boatmen's travel. Each boat might have made a total of eight to ten such trips per year if Po navigation followed the rhythms the table suggests.

In economic terms, if we hypothesize, conservatively, that such a boat transported two tons of wares upstream, this would mean that each year each boat could have moved up the Po network about sixteen to twenty tons of salt, wine amphoras, and the like from Comacchio, and carried a similar volume of goods back to the home port ${ }^{76}$. Larger barges would have expanded the potential volume of their activity commensurately. Even if contemporary Po barges reached the much bigger size of the eight or so tonners that worked the Carolingian Rhine, multiple river boats would still have been needed to transport inland the wares of an early medieval merchant seagoing ship whose cargo o might have run about thirty five to fifty tons ${ }^{77}$.

From these considerations and convergent seasonal rhythms flow two important corollaries. The first is that because salt-producing, Po river transport, and Mediterranean shipping seasons mostly overlapped, it is unlikely that the same people made the salt, shipped and sold it upriver, and also sailed overseas to get long-distance goods elsewhere in Italy or further afield. In other words, the convergent seasonal ecology of these three activities imposed a specialization of labor, unlike what we see, for instance, with some ninth-century Rhenish potters who sold their own products up the Rhine. ${ }^{78}$ Since Comacchiesi towed their boats up the Po and presumably made the salt, these social and

\footnotetext{
${ }^{76}$ Uncertainty about the regularity of the Po flow and depth urges great caution here. A "tithe" (decima) of a Comacchio boat's salt cargo according to the pactum of 715, ed. Hartmann, Zur Wirtschaftsgeschichte Italiens, p. 124, could be taken to imply that the salt component of a boat load weighed 5,400 Roman pounds, that is, according to the Constantinian reform in which a pound weighed ca. $324 \mathrm{~g}$., about $1750 \mathrm{~kg}$., i.e. a total boat capacity of around 2 metric tons. This would not require a large river boat by earlier Roman or Carolingian standards: see next note.

${ }^{77}$ A Carolingian river transport barge from the Rhine is estimated to have had a capacity of eight or nine tons: McCormick, Gibson and More, "Concise geodatabase of shipwrecks AD 1-1500," s.v. "Krefeld Gellep 3", with further references. For archaeologically documented early medieval ship capacities, McCormick, Origins, p. 416, Table 13.1.

${ }^{78}$ Ibidem, p. 658.
} 
economic actors must have been different and coexisted simultaneously at Comacchio. We have, on the other hand, no unambiguous references to Comacchio ships in the Adriatic or anywhere else in the Mediterranean in the eighth and ninth centuries. It is conceivable that some, perhaps much of the wares that reached the wharves of Comacchio got there in ships whose homeport lay elsewhere. In this context, a ninthcentury report about a monk of Comacchio bears repeating. Returning from pilgrimage to the Holy Land in the 820s, the monk Dominic took a Venetian ship home from Alexandria. It is of course possible that the Venetian convoy was the first transit available. But we may also suspect that there were no ships from Comacchio in Alexandria's harbor those weeks. This might have a more general bearing on who was carrying Mediterranean wares to Comacchio at that date ${ }^{79}$.

The second corollary is that at least some of the wares that arrived or were produced in Comacchio in the later part of the summer only became available too late in the year to be carried immediately upstream toward Pavia and Milan. If it is true that Po shipping diminished considerably late in the season -again, a point which requires closer study--, that would imply that such goods had to be stored in Comacchio over the winter. The immobilization of capital that this entailed would imply lesser efficiency in deploying the wealth that financed imports and production at Comacchio. At the same time, these seasonal rhythms would suggest that the local boatmen and merchants wanted to get underway as early in the spring as conditions would have warranted, to begin to turn their stockpiled wares -and immobilized capital - into profit as quickly as possible. It may therefore be no accident that the Comacchio traders who concluded the agreement with the Lombards in 715 were in Pavia by 15 May that year.

Exotic wares have from the beginning figured as distinctive features of the emporia, so there is little need to insist on them. Nevertheless it is worth emphasizing that the emporia were economic phenomena, and that economics is not only about structures. It is also about quantities. Hence the importance of even rough estimates of transport capacities and aggregate volume of wares. Configurations of relations among emporia presumably underwent constant change, as demand increased in one region and ebbed in

\footnotetext{
${ }^{79}$ Translatio Marci, ed. N. McCleary, "Note storiche ed archeologiche sul testo della Translatio sancti Marci”, Memorie storiche Forogiuliesi, 27-29 (1931-1933), p. 225-264, here p. 257.20-258.3.
} 
another, as new networks rose and old ones declined. To be able to see and track these changes, we need to quantify the visible proportions of imported and exported wares. Most importantly, we need to quantify to be able to assess their economic significance. Only by so doing was Janssens able to show that the Rhenish ware discovered at Haithabu, and which attracted such attention, was in fact only a very small percentage of all similar ceramic. The Rhenish vessels also showed a peculiar spatial distribution. That they concentrated in certain houses led Janssens to conclude that in all probability these finewares were not traded goods, but items that traders brought with them from the Rhineland for personal use. They thus point indirectly to the geographical horizons of the traders' activity, but are not themselves direct evidence for trade, and certainly tell us nothing about the volume of wares traded ${ }^{80}$. Thoughtful quantification should lead to a comparative list of how much of what was imported from how far, and how the proportions changed over time. That will begin to shed some light on the sensitivities of growing, declining, changing markets and trade networks: patterns of supply, but also of demand.

In the course of these much-to-be-desired studies, careful scholars will consider what we cannot see. Many -most?-- wares likely or certainly traded through certain sites have left few obvious material traces when they were not produced on site: textiles, slaves, speciality woods, spices, furs, honey, wax, salt, perhaps even some precious ancient books if we were to suspect that a famous fifth-century manuscript of Livy was purchased at Dorestad. As unlikely a place as it might seem for a crucial link in the chain of transmission of ancient literature, the fact remains that a great ancient codex, the sole surviving witness to Livy's Fifth Decade, belonged to someone at Dorestad, whether because it had traveled there from Italy in some merchant or pilgrim's sack or because it got there in some other way. Around 800, the book was owned by a man who identifies himself, rather mysteriously, as "Theatbertus episcopus de Dorostat." ${ }^{\text {"T1 }}$ Dorestad was not

\footnotetext{
${ }^{80}$ W. Janssen, Die Importkeramik von Haithabu, Neumünster, 1987 (Ausgrabungen in Haithabu 9), p. 7075 and p. 132-136.

${ }^{81}$ Vienna, Österreichische Nationalbibliothek, 15. See E. A. Lowe, Codices latini antiquiores: $a$ palaeographical guide to Latin manuscripts prior to the ninth century, Oxford, 1934-1972, p. 10, no. 1472 , who mentions the possible identification with Thiaterd bishop of Utrecht, and B. Bischoff, "Lorsch im Spiegel seiner Handschriften", in Die Reichsabtei Lorsch. Festschrift zum Gedenken an ihre Stiftung 764, ed. F. Knöpp, 2, München, 1974, p. 7-128, here p. 64, who hypothesizes that the book got there thanks to an Anglo-Saxon missionary who brought it from home or from a trip to Italy. However, given the great
} 
a bishopric, but Theatbert's title raises the question of the ecclesiastical status of the new emporia - a question that was quickly settled in the Adriatic, but not in the north. ${ }^{82}$ This important difference of ecclesiastical organization between the Adriatic trading sites and the northern ones probably helps explain why the Adriatic settlements enjoyed greater permanence than their northern counterparts.

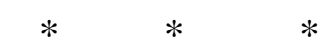

This selective check list of the emporia's systemic and material features is only a beginning for further reflection. Among systemic features, locations and ecological, transport, political and cultural transitions loom large. Evidence for princely foundation of some emporia looks shaky; many emporia show a paradoxical proximity but separation from a larger, more populous zone. This "near but far" feature for some trading townlets may reflect an initial "offshore" and unregulated status connected with avoiding restrictions and taxes on trade, including, in Comacchio's case, illicit trade with the Lombards.

Among material features, the initial absence of defensive structures reflects the broader sense of security that commerce needs to flourish; the relative sizes and differing structures - polyfocal versus mononucleic - distinguish emporia, or groups of emporia, at least at some points in their existence. Trash in substantial quantities signals a denser population. How it was managed (or not), casts light on the emporia's organizational structures, while the presence of waster products from craft activity and refuse from luxury diets point to some of the residents' non-agrarian activities and unusual wealth.

Emporia feature an exceptional density of money or the precious metals which served as standards of value. Coins of distant origin appear alongside local mint production fired by concentrated demand for coins, a demand that encouraged the circulation of imitation and also counterfeit coins in these hotspots of commercial activity. This explains the need for touchstones in emporia, as well as the fine scales and weights suited to measuring coins and other precious substances that turn up there.

value that Carolingian scholars attached to ancient manuscripts, one cannot but wonder whether there was not some trade in them as well, including in the markets of the emporia.

${ }^{82}$ The way Theatbertus describes himself suggests that he may have been of chorepiscopus (i.e. auxiliary rural bishop) assigned to Dorestad from the Utrecht see to which the port belonged. 
Transport animals and gear, and the traces on human skeletons of heaving, hauling and carrying should appear regularly on trading sites because of the need to move wares. Elements of carts, boats and landing gear can be expected whether as derelict materials or recycled into other uses. So too some of the stouter containers such as barrels and amphoras as well as the occasional basket when preservation conditions allow. Where barrels competed with amphoras, we might get some insight into the changing scale of trade, and dendrochronological analysis eventually will allow precise dating and localization of the barrels. How the containers were grouped and stored holds further insights into how early medieval people imagined and organized their commerce, as well as into its scale. The need to insure the security of the valuables that each trader brought or sought in the emporium implies locks and keys; the need to keep valuable human wares from running away explains the presence of iron shackles for the slave trade. Weapons too were part of early medieval traders' kits.

Specialized craft production has long been a classic signal of an emporium. We would gain from trying to see the broad and changing constellation of workshops and their production activities in a particular emporium and its hinterland. The craftsmen's experience of a new, unfettered but also unsupported social context of production may well have helped elicit a new mentality and new approaches to production. The networks that supplied raw materials for the workshops ranged near and far, and are an obvious but still under-studied part of the picture.

Every emporium's activities surely followed seasonal rhythms. They need more investigation in each place, and we need to compare them among emporia and consider how they may or may not have been coordinated from trading node to trading node. External constraints, such as the season of safe sailing on the Mediterranean or the flood patterns of the Po, played an important role, as did the seasonal butchering animals, shearing of sheep, producing of salt, and trapping of furs. A first review of production and transport sectors suggests a labor crunch at Comacchio in late summer. It also gives a first indication of how fast a Comacchio boatman could accomplish a trading trip up the Po, and how many such profit opportunities he might have had each year. This begins to sketch in the parameters for posing the crucial question of the changing volume of goods that moved through and thanks to Comacchio. 
So these are some of the systemic and material features that we can expect in most trading settlements, including Comacchio. Let us not lose sight of the fact that we are just beginning at Comacchio: this is Birka in the 1890s, Kaupang ca. 1960, Dorestad in the 1930s. Future knowledge here is still in the future. Yet the fact that the Comacchio team is capitalizing on archaeological experience in the north augurs well for the future of the early medieval trading past of Comacchio and of Europe more broadly. If the work begun on this site continues, and if all who are interested in the emergence of the European economy keep an eye on how our knowledge of the various centers grows and changes, then answers will be forthcoming. Those answers will lead to the comparative understanding, and even the historical connections among these remarkable new entities that played such an extraordinary role in the origins of medieval Europe's economic networks. However short their life span, the early medieval trading towns connected and fostered, in the long run, the economic networks that they would transform and develop into the systems that spread from Europe outward in one long and tumultuous --but continuous-- process of development. This is the early face of a globalization which in some meaningful sense continues even today, relayed and reinforced by new trading worlds that emerged out of the tiny, hesitant beginnings we perceive in the emporia of early medieval Europe. 